\title{
A Tentative Study on Tax Planning for Corporate Income Tax of PPP Projects \\ Cong LI
}

Beijing Institute of Fashion Technology, Beijing 100000, China

Keywords: PPP projects, Corporate income tax, Tax planning.

\begin{abstract}
At present, the taxation of PPP projects in China is mainly reflected in the VAT and Corporate income tax. Problems with the Corporate Income Tax Treatment of PPP Projects are mainly reflected in the amount of taxable income, which is the starting point. Combined with the types of PPP projects, this paper explores the Corporate income tax planning of PPP projects.
\end{abstract}

\section{Introduction}

At present, China's economic development has entered a new normal, and the entire society's investment structure and investment methods have also undergone some changes. The demand for public goods supply and infrastructure construction has increased rapidly. Faced with this development status, the PPP model has been widely promoted and applied in China. Since 2014, the State Council, the Ministry of Finance, the National Development and Reform Commission and other departments have issued dozens of documents to vigorously promote the application of cooperation models of government and social capital. However, the PPP model project has a long period of time, generally more than ten years, making the future of the project more uncertain and risky, and the tax policy plays an important role in controlling the risk under the PPP model. Therefore, to give full play to the advantages of PPP public-private cooperation, we need to improve tax policies. The improvement of taxation policy for corporate income tax is particularly important.

\section{Tax Status of PPP Projects and Main Problems in Corporate Income Tax of PPP Projects}

Tax Status of PPP Projects. The PPP model is a cooperation between social capital and the government. It refers to a way in which public relations departments provide public goods services by establishing partnerships with social capital parties. It is mainly applicable to public services and infrastructure where the government has responsibility and is suitable for market operation.

Table 1. PPP project types and Charge method

\begin{tabular}{|l|l|l|l|}
\hline PPP project types & $\begin{array}{l}\text { Operating } \\
\text { projects }\end{array}$ & Quasi-operating project & $\begin{array}{l}\text { Non-operating } \\
\text { project }\end{array}$ \\
\hline Charge method & User pays & $\begin{array}{l}\text { User pays and } \\
\text { Government subsidies }\end{array}$ & Government subsidies \\
\hline
\end{tabular}

In general, China's tax policy on PPP projects still has major deficiencies, and it is still in a state of fragmentation. The related tax policy system is waiting for improvement[1]. Problems with the tax are mainly reflected in the following aspects: taxation issues for some special PPP projects are poorly considered; PPP project tax preferential policies coverage is too narrow; tax relief policy and the current tax reform do not adapt to the others.

The PPP model project has a long period of time, generally more than ten years, making the future of the project more uncertain and risky. The tax policy plays an important role in the control of risks under the PPP model. Therefore, the PPP model should be used as a public-private partnership. With regard to advantages, it is necessary to improve tax policies and give full play to the role of tax policies.

At present, the taxation of PPP projects in China is mainly reflected in the two kinds of VAT and Corporate income tax[1,2]. The following is a study of the main taxation issues of Corporate income tax for PPP projects. 
Main Problems in Corporate Income Tax of PPP Projects. There are three kinds of government return mechanisms for PPP projects: government fees, feasibility gap subsidies, and user fees. Many PPP projects calculate the corporate income tax by $25 \%$ according to the calculations of conventional companies. This calculation method is considered to be wrong. The reasons are as follows:

(Operating projects) For user-paid items, the operating income obtained by the project company from the market is not substantially different from that of other companies in the market. Taxes can be made according to regulations. However, for government-paid and viable PPP projects with a gap subsidy model(Quasi-operating project), where the government's fiscal revenue is equal to other market operating income, it is equivalent to a $25 \%$ income tax on this part of the income. The tax will inevitably be passed on to the government, which means that the government must increase its payment by $25 \%$ to meet the return on investment of social capital. Corporate income tax belongs to the national tax, which is equivalent to the state's pocketing of money from local governments for local government-paid PPP projects, which will increase the debt pressure of local governments, contrary to the original intention of implementing the PPP model to ease the pressure on local debt. For the PPP project with viable gap subsidy, this is because the user is not paying enough, so the government needs to pay for the gap. If the income tax is levied on the user's paid income, it will inevitably need to increase the gap subsidy, or will increase the government burden. Therefore, corporate income tax should not be levied on government-paid projects and feasibility gap subsidy projects. At present, most PPP consulting agencies have mistakes in the calculation of corporate income tax, which imposes a heavier burden on local governments.

\section{Tax Planning for Corporate Income Tax of PPP Projects}

Considering that the PPP project has a long period of time, the government needs to perform tax accounting on the enterprise income tax each year. In order to meet the project's expected return on investment and make the PPP model risk sharing play a successful role in the implementation of the project, the method of the present value of the annuity is used. Based on the operating cash flow of each year, it compares with the annuity and determines the taxation in each case. The tax planning of the PPP project's corporate income tax is carried out on the following three types of projects under the PPP model.

Tax Planning for Corporate Income Tax of Operating Projects. In terms of operating projects, this kind of PPP project adopts the "user pays" model, and it is expected that the operating charges will cover all the items of investment costs. Taking the Beijing Subway Line 4 as an example, the preliminary estimate of the Beijing Subway Line 4 is a total investment of 15.3 billion yuan. The Beijing Subway Line 4 can be divided into two parts, A and B, according to the responsibility for construction. Part A is mainly civil works, with a total investment of about 10.7 billion yuan, accounting for about $70 \%$ of the total investment of the project. This part is invested by the Beijing 4th Line Investment Company, which represents the government; and Part B mainly includes the vehicle, signal, and automatic ticketing system. Part B mainly includes mechanical and electrical equipment such as vehicles, signals, automatic ticketing and ticketing systems, etc. This part of the investment amounted to 4.6 billion yuan, accounting for about $30 \%$ of the total project investment. Beijing MTR, which represents private capital, is responsible for investment and construction and later operations. After the completion of the project, the project will give Beijing MTR Corporation (social capital) a franchise for 30 years. After the franchise is over, the Beijing MRT transferred the project to the department designated by the municipal government without compensation.

The Beijing MTR Corporation (social capital) will collect investment through subway ticket revenue and business income from subway stations. This is in line with the operating mode of the PPP model.

Table 2. The part of PVIFA

\begin{tabular}{|l|l|l|l|l|l|l|l|l|}
\hline $\mathrm{n}$ & $1 \%$ & $2 \%$ & $3 \%$ & $4 \%$ & $5 \%$ & $6 \%$ & $8 \%$ & $10 \%$ \\
\hline 30 & 25.087 & 22.396 & 19.6 & 17.292 & 15.372 & 13.764 & 11.257 & 9.426 \\
\hline
\end{tabular}


The social capital of the project is expected to have a return on investment of $10 \%$. Equations(1) and Table 2 , the annuity will be 4.8805 billion yuan.

$$
\mathrm{A} \times(\mathrm{P} / \mathrm{A}, 10 \%, 30)=46 \text {. }
$$

In the 30 years during which the Beijing MTR has a franchise, if the operating cash flow during the year is equal to 4.8805 billion yuan, the tax for that year may be exempted; If the operating cash flow during the year is less than 4.8805 billion yuan and the operating cash flow is 4 billion yuan, a certain amount of tax subsidies can be carried out, such as $25 \%$ of the amount of subsidy losses, and the subsidy amount is (4.8805-4) x $25 \%=0.2201$ billion yuan; If the operating cash flow in that year is greater than 4.8805 billion yuan, it can be carried out on a piecemeal basis. Partial tax rates of up to 5 million yuan are $10 \%$, and part of the tax rates of more than 5 billion yuan but not exceeding 6 billion yuan is 15\%, the partial tax rate is $20 \%$, exceeding 6 billion yuan.

From the example of the Beijing Subway Line 4, if you want to make the tax policy play a proper role in the control of the risk under the PPP model, the taxation rules for corporate income tax under the PPP model should start with the operating cash flow. The the following tax regulations can be made for the Operating Projects in the PPP mode: Within the period of time when social capital has franchise rights, its tax revenue can be determined based on the annual operating cash flow of the project. For the case where the annual operating cash flow equals the annuity, no tax is charged; for the case where the annual operating cash flow is less than the annuity, for a part that is less than that, a certain percentage of tax subsidies are carried out; For the case where the annual operating cash flow is greater than the annuity, the annuities that are higher than those of an annuity can raise the tax rate relatively. Different from the range, the tax rate is different.

Tax Planning for Corporate Income Tax of Quasi-operating projects. For quasi-operating projects, because the operating charges during the franchise period are not sufficient to completely cover the investment costs, the government is required to grant subsidies each year while granting franchise rights to social capital. When the project does not work, the government takes over. Take the financing and construction of the National Stadium (Bird's Nest) as an example. The National Stadium (Bird's Nest) PPP project has a total investment of nearly 3.2 billion yuan, of which $58 \%$ is funded by the government and $42 \%$ is invested by CITIC Union Group. This part serves as social capital. The government is responsible for the construction. The CITIC Union Group is responsible for the operation and maintenance of the National Stadium after the Olympic Games. The franchise period is 30 years. After the Olympic Games, due to the lack of sufficient commercial income support, the operation of the Nestle was in an operational dilemma. On August 29, 2009, the Beijing Municipal Government took over the operation. The National Stadium PPP project can be seen as a quasi-operating project. If the future revenue cannot cover the investment cost, the government should give corresponding subsidies.

The social capital of the project is expected to have a return on investment of $10 \%$. According to Equations(2) and Table 2, the annuity will be 1.4258 billion yuan.

$\mathrm{A} \times(\mathrm{P} / \mathrm{A}, 10 \%, 30)=13.44$.

In order to encourage the PPP model, before the government took over the operation on August 29,2009 , the taxation method for corporate income tax is the same as the taxation method for operating projects. It should be noted that the government grants during this period should not be included in the operating cash flow as the tax base. if the operating cash flow (the government grant is not included in this) during the year is equal to 1.4258 billion yuan, the tax for that year may be exempted; If the operating cash flow (the government grant is not included in this) during the year is less than 1.4258 billion yuan a certain amount of tax subsidies can be carried out, such as $25 \%$ of the amount of subsidy losses. If the operating cash flow (the government grant is not included in this) in that year is greater than 1.4258 billion yuan, it can be carried out on a piecemeal basis. Partial tax rates of up to 2 million yuan are 10\%, and part of the tax rates of more than 3 billion yuan but not exceeding 4 billion yuan is $15 \%$, the partial tax rate is $20 \%$, exceeding 4 billion 
yuan. After the government took over the operation on August 29, 2009, it no longer involved income tax issues.

From the example of the National Stadium (Bird's Nest), it can be concluded that in the case of Quasi-operating project, the taxation of corporate income tax under the PPP model should take the time taken by the government as the time demarcation point for tax collection. Make the following tax rules: before the government takes over the operation, The taxation method for the enterprise income tax of quasi-operating projects refers to the taxation policy of the business projects mentioned above. The government grants during this period should not be included in the operating cash flow as the tax base. After the government took over the operation on August 29, 2009, it no longer involved income tax issues.

Tax Planning for Corporate Income Tax of Non-operating Project. For non-operating projects, social capital cannot use the "user pays" method to recover investment costs, and can only use the "government subsidies" approach to recover investment costs. Therefore, tax-related issues are basically not involved, so the taxation of non-operating projects under the PPP model is not stated as an important content here.

\section{Summary}

The PPP model will be an important way for the construction and operation of public service and infrastructure projects. Corporate income tax planning plays an indispensable role in the success of the PPP project. This paper takes the company's operating cash flow as the tax base for corporate income tax, and carries out the tax planning of the corporate income tax for three different projects in the PPP model. We hope to reduce or control the risk of PPP projects through the corporate income tax policy, mediate the interests of both parties, and promote the promotion of the PPP model.

\section{Acknowledgments}

This research was financially supported by the Thesis Project Funding of Beijing Institute of Fashion Technology.

\section{References}

[1] Ming-wei Ji. Tax risk of PPP project [EB/OL]. China construction network, 2015-10-16.

[2] Xiao-min Yang. PPP project planning and operation practice [M]. Beijing: China construction industry press, 2015. 